\title{
PENGARUH KEBIJAKAN HARGA, PROMOSI DAN DISTRIBUSI TERHADAP KEPUTUSAN PEMBELIAN MINUMAN PRODUK COCA-COLA DI KOTA PADANG
}

\author{
Fasridon \\ Fakultas Ekonomi Universitas Putra Indonesia YPTK Padang \\ fasridon@gmail.com
}

\begin{abstract}
ABSTRAK
Penelitian ini bertujuan untuk mengungkap sejauh mana (1) Pengaruh kebijakan harga terhadap keputusan pembelian, (2) Pengaruh promosi terhadap keputusan pembelian, (3) Pengaruh distribusi terhadap keputusan pembelian, (4) Pengaruh kebijakan harga, promosi dan distribusi secara serentak/simultan terhadap keputusan pembelian. Populasi dalam penelitian ini tidak teridentifikasi atau tidak diketahui secara pasti. Pengambilan sampel dengan menggunakan rumus Hair, et Al (1998) diperoleh sampel sebanyak 100 responden. Metode yang digunakan dalam penelitian ini adalah metode simple random sampling. Hasil dari penelitian menunjukkan bahwa variabel kebijakan harga secara parsial berpengaruh positif dan tidak signifikan terhadap keputusan pembelian, sedangkan variabel promosi dan varibel distribusi secara parsial berpengaruh positif dan signifikan terhadap keputusan pembelian. Hasil penelitian ini juga menunjukan variabel kebijakan harga, promosi dan distribusi secara serentak/simultan berpengaruh positif dan signifikan terhadap keputusan pembelian
\end{abstract}

Kata kunci : Kebijakan Harga, Promosi, Distribusi

\section{PENDAHULUAN}

Perkembangan dunia usaha industri minuman ringan mengalami peningkatan setiap tahun. Hal ini terbukti dengan semakin banyaknya pendatang/pebisnis baru yang memasuki pasar dengan berbagai strategi yang digunakan demi menarik konsumen sebanyak mungkin. Oleh karena itu, perusahaan tidak hanya berusaha mendapatkan konsumen yang baru tetapi juga berusaha untuk mempertahankan pelanggan yang telah mereka dapatkan. Dalam persaingan memasarkan produk dengan tujuan menciptakan pelanggan, perusahaan perlu membangun strategi pemasaran yang baik. Strategi yang harus dilakukan dalam upaya mencapai target pemasaran dimulai dari dalam perusahaan, khususnya produk yang diciptakan harus mendapatkan perhatian dari konsumen sehingga konsumen dapat memutuskan untuk membeli produk yang diciptakan oleh perusahaan tersebut.

Strategi pemasaran terdiri dari unsur-unsur pemasaran yang terpadu (4P, yaitu product, price, promotion, place) yang selalu berkembang sejalan dengan gerak perusahaan dan perubahan-perubahan lingkungan pemasaran serta perubahan perilaku konsumen. Perilaku konsumen mempunyai implikasi sangat luas terhadap perumusan strategi pemasaran. Hal ini disebabkan karena strategi pemasaran menyangkut dua kegiatan pokok yang diantaranya adalah pemilihan pasar-pasar yang akan dijadikan sasaran pemasaran, serta merumuskan dan menyusun suatu kombinasi yang tepat dari marketing mix agar kebutuhan konsumen dapat dipenuhi secara memuaskan.

Keputusan pembelian merupakan pengambilan keputusan konsumen yang merupakan proses pemecahan masalah yang di arahkan pada sasaran. Pemecahan masalah konsumen sebenarnya merupakan suatu aliran tindakan timbal balik yang berkesinambungan di antara faktor-faktor lingkungan, proses efektif, serta tindakan perilaku.

Harga dapat mempengaruhi keputusannya dalam membeli suatu produk sehingga suatu perusahaan harus mampu memberikan kebijakan yang baik terhadap produk atau jasa yang mereka jual.

Menurut Buchari Alma (2011) Harga adalah suatu atribut yang melekat pada suatu barang, yang memungkinkan barang tersebut, dapat memenuhi kebutuhan (needs), keinginan (wants) dan memuaskan 
konsumen (satisfaction). Berdasarkan pendapat tersebut, harga mempunyai arti bahwa kebijakan harga merupakan alat, pegangan yang dipakai oleh perusahaan untuk menentukan harga dalam jangka waktu tertentu dan menetapkan harga jual perusahaan untuk mempengaruhi konsumen dalam melakukan pembelian terhadap barang yang ditawarkan.

Promosi menurut Buchari Alma (2006) adalah sejenis komunikasi yang memberi penjelasan dan meyakinkan calon konsumen mengenai barang dan jasa dengan tujuan untuk memperoleh perhatian, mendidik, mengingatkan dan meyakinkan calon konsumen. Promosi merupakan alat komunikasi dan penyampaian pesan bersifat memberitahukan, membujuk, mengingatkan kembali kepada konsumen, para perantara atau kombinasi keduanya.

Pelaksanaan kegiatan promosi tentu saja tidak dapat berdiri sendiri, artinya kegiatan promosi bukan merupakan satu-satunya variabel yang paling menentukan dalam peningkatan volume penjualan karena berkaitan juga dengan faktor-faktor lainnya seperti : trend pasar, variasi produk, peraturan pemerintah, dan variabel lain yang mungkin di luar kendali perusahaan. Dalam kegiatan promosi perusahaan mengharapkan pembeli yang potensial menjadi pembeli aktual selain untuk mempertahankan pelanggan yang sudah ada. Mengingat semakin sengitnya persaingan dalam memperebutkan pasar, perusahaan terus terpicu untuk memperbaiki kinerjanya terkait dengan permasalahan di atas agar volume penjualan dapat dipertahankan bahkan ditingkatkan.

Menurut Kotler Philip (1991) distribusi adalah sekelompok perusahaan atau perseorangan yang memiliki hak pemilikan atas produk atau membantu memindahkan hak pemilikan produk atau jasa ketika akan dipindahkan dari produsen ke konsumen

Perusahaan Coca-Cola dalam mengantarkan produk sampai ke outlet /pelanggan dilakukan secara langsung (direct distribution customers) dan tidak langsung (indirect distribution customers) melalui mitra distribusi. Perusahaan Coca-Cola juga mempunyai cara tersendiri dalam mendistribusikan produk-produknya. Pertimbangan efisiensi biaya dan kecepatan dalam menjaga availability (ketersediaan) produk sangat diutamakan. Panjang pendeknya mata rantai saluran distribusi tergantung pada jumlah perantara yang berada diantara produsen dan konsumen. Semakin panjang mata rantai distribusi, maka biaya distribusi akan semakin tinggi.

Perusahaan Coca-Cola merupakan salah satu perusahaan minuman yang cukup mendunia dengan penguasaan pasar yang sudah cukup merata diseluruh dunia. Produk-produk minuman dari perusahaan Coca-Cola tersebut seperti Coca-Cola Sprite, Fanta, dan berbagai produk minuman kategori baru yang beredar dipasaran.

Sebagai perusahaan minuman terbesar di dunia, perusahaan Coca-Cola tidak hanya memiliki banyak keunggulan, namun juga mulai muncul sisi kelemahannya yang berindikasi pada larinya para konsumen meninggalkan produk minuman dari perusahaan tersebut. Perusahaan Coca-Cola memiliki beberapa kelemahan diantaranya adalah bentuk inovasi serta ekspansi yang lambat dari perusahaan dalam mengatasi pesaing serta upaya memenuhi keinginan dari pasar yang terus meningkat. Masalah lainnya adalah menurunnya konsumsi pasar terhadap produk minuman berkarbonasi.

Permasalahan yang dihadapi Coca-Cola pada saat ini adalah bertahan di tengah peralihan konsumen yang mulai meninggalkan minuman berkarbonasi dan bersoda beralih kejenis minuman lain yang menjaga kesehatan. Hal ini dapat dilihat dari menurunnya penjualan untuk tahun $2013-2015$ ratarata $12.5 \%$ setiap tahun nya (sumber PT. Coca-Cola Distribution Padang).

Kota Padang merupakan bagian dari Sumatera Tengah dimana terdapat pusat-pusat perbelanjaan dan mini market yang menyediakan minuman-minuman ringan seperti Coca-Cola. Pangsa pasar minuman produk Coca-Cola di Kota Padang merupakan daerah wisata dan kos-kosan mahasiswa maupun karyawan.

Berdasarkan uraian dan fenomena yang telah dipaparkan sebelumnya, dapat ditarik kongklusi bahwa kebijakan harga, promosi dan distribusi merupakan variabel yang sangat penting dalam menentukan keputusan pembelian minuman produk Coca-Cola. Walaupun demikian, hingga saat ini, masih relatif terbatasnya penelitian empiris terdahulu yang mencoba menganalisis bagaimana dampak variabel kebijakan harga, promosi dan distribusi terhadap keputusan pembelian minuman Coca-Cola di 
Kota Padang. Oleh karena itu, penulis tertarik untuk mengkajinya lebih mendalam yang penulis tuangkan dalam bentuk tesis dengan judul "Pengaruh Kebijakan Harga, Promosi Dan Distribusi Terhadap Keputusan Pembelian Minuman produk Coca-Cola di Kota Padang”

\section{TINJAUAN PUSTAKA}

2.1 Keputusan Pembelian

Menurut Etta Mamang Sangadji dan Sopiah (2013) Pengambilan keputusan konsumen adalah proses pemecahan masalah yang di arahkan pada sasaran. Pemecahan masalah konsumen sebenarnya merupakan suatu aliran tindakan timbal balik yang berkesinambungan di antara faktor-faktor lingkungan, proses kognitif dan efektif, serta tindakan perilaku. Periset dapat membagi aliran ini ke dalam beberapa tahap dan subproses yang berbeda untuk menyederhanakan masalah (problem solving) genetik yang menjelaskan lima tahapan atau proses dasar. Model dasar di atas menunjukkan beberapa kegiatan penting yang terlibat dalam pemecahan masalah : pengaktifan motivasi awal untuk terlibat dalam pemecahan masalah, pencarian informasi yang relevan dengan masalah yang dihadapi, pengevaluasian alternatif tindakan, dan pemilihan tindakan yang akan dilakukan.

Menurut Fandy Tjiptono (2008) Berdasarkan tujuan pembelian, konsumen dapat diklasifikasikan menjadi dua kelompok, yaitu konsumen akhir (individual) dan konsumen organisasi (konsumen industri, konsumen antara konsumen bisnis). Konsumen akhir terdiri atas individu dan rumah tangga yang tujuan pembeliannya adalah untuk memenuhi kebutuhan sendiri atau untuk dikonsumsi. Sedangkan konsumen organisasional terdiri atas organisasi, pemakai industri, pedagang, dan lembaga non profit.

Menurut Thamrin Abdullah dan Francis Tantri (2012) Proses pembelian konsumen melalui lima tahap yaitu pengenalan masalah, pencarian informasi, evaluasi alternatif, keputusan pembelian, dan perilaku purna beli. Jelaslah bahwa proses pembelian dimulai jauh sebelum pembelian aktual dan mempunyai konsekuensi lama setelah pembelian.

\subsection{Kebijkan Harga}

Harga didefinisikan sebagai kemampuan seseorang dalam menilai suatu barang dengan satuan alat ukur rupiah untuk dapat membeli produk yang ditawarkan. Menurut Buchari Alma (2011) Harga adalah suatu atribut yang melekat pada suatu barang, yang memungkinkan barang tersebut, dapat memenuhi kebutuhan (needs), keinginan (wants) dan memuaskan konsumen (satisfaction).

Menurut Hendra Fure (2013) Definisi lain harga adalah segala sesuatu yang diberikan oleh pelanggan untuk mendapatkan keunggulan yang ditawarkan oleh bauran pemasaran perusahaan.

Menurut Buchari Alma (2011) menyatakan bahwa kebijakan atau price politicies = produk harga adalah keputusan mengenai harga-harga yang akan di ikuti untuk suatu jangka waktu tertentu. Sedangkan menurut Birrul (2009) menyatakan bahwa kebijakan harga adalah suatu alat atau cara yang dipergunakan perusahaan untuk menetapkan harga dan bisa mempengaruhi konsumen dalam melakukan pembelian terhadap barang yang ditawarkan. Keputusan penetapan harga mempengaruhi jumlah penjualan yang dilakukan oleh perusahaan dan berapa banyak pendapatan yang diperoleh. Pada umumnya harga ditetapkan melalui negosiasi antara pembeli dan penjual. Tawar menawar masih merupakan permainan di beberapa wilayah. Menetapkan satu harga untuk semua pembeli merupakan gagasan yang relatif modern yang muncul bersama perkembangan eceran berskala besar.

\subsection{Promosi}

Promosi merupakan salah satu variabel di dalam marketing mix yang sangat penting dilaksanakan oleh perusahaan dalam pemasaran produk atau jasanya. Menurut Martin L. Bell dalam Swastha dan Irawan (2005) promosi adalah semua jenis kegiatan pemasaran yang ditujukan untuk mendorong permintaan. Promosi adalah arus informasi atau persuasi satu arah yang dibuat untuk 
mengarahkan seseorang atau organisasi kepada tindakan yang menciptakan pertukaran dalam pemasaran.

Di sisi lain menurut Fandy Tjiptono (2008) promosi penjualan adalah bentuk persuasi langsung melalui penggunaan berbagai insentif yang dapat diatur untuk merangsang pembelian produk dengan segera dan meningkatkan jumlah barang yang dibeli pelanggan. Sedangkan pengertian promosi menurut Buchari Alma (2006) adalah : "Promosi adalah sejenis komunikasi yang memberi penjelasan dan meyakinkan calon konsumen mengenai barang dan jasa dengan tujuan untuk memperoleh perhatian, mendidik, mengingatkan dan meyakinkan calon konsumen".

\subsection{Distribusi}

Distribusi proses pemindahan barang-barang dari tempat produksi ke berbagai tempat atau daerah yang membutuhkan. Kotler (2005) mendefinisikan bahwa distribusi akan mencakup perencanaan, pelaksanaan dan pengawasan arus bahan dengan memperoleh produk akhir dari tempat produksi dengan memperoleh keuntungan. Sebagian besar perusahaan menyatakan bahwa tujuan distribusi adalah membawa barang dalam jumlah tepat, pada waktu yang tepat, dan dengan biaya serendah mungkin.

Berdasarkan telaah pusaka yang telah dilakukan di atas, maka model pemikiran teoritis yang dikembangkan pada penelitian ini terlihat pada gambar berikut ini :

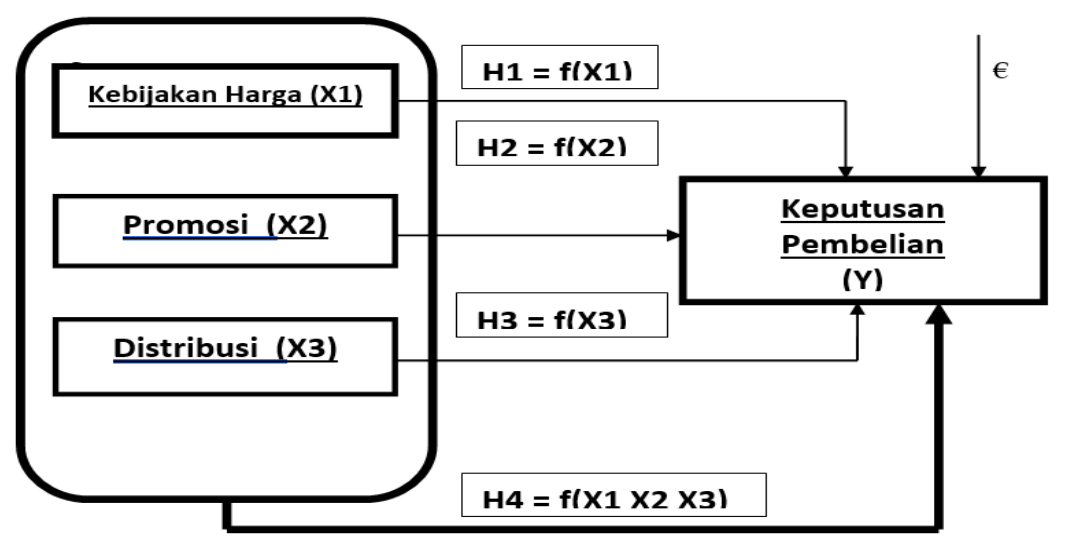

Gambar 2.1 : Kerangka Konseptual

\section{METODE PENELITIAN}

Metode yang digunakan dalam penelitian ini adalah metode survey. Metode survey menurut Sugiono (2009) adalah penelitian yang dilakukan pada populasi besar maupun kecil, tetapi data yang dipelajari adalah data dari sampel yang diambil dari populasi tersebut, sehingga dapat ditemukan kejadian-kejadian relatif, distributif dan hubungan antar variabel, sosiologis maupun psikologis. Sedangkan bentuk penelitiannya adalah penelitian deskriptif. Penelitian deskriptif adalah mempelajari masalah-masalah deskriptif dalam masyarakat, serta tata cara yang berlaku dalam masyarakat serta situasi-situasi tertentu, termasuk tentang hubungan kegiatan-kegiatan, sikap-sikap, pandangan serta proses-proses yang sedang berlangsung dan pengaruh-pangaruh dari fenomena. Dalam penelitian ini, metode deskriptif bertujuan mengugkap atau menjelaskan karakteristik dari masing-masing variabel yang diteliti. Dalam penelitian survei hasil akhir hanya menjelaskan karakteristik variabel dengan variabel lainya (secara parsial dan simultan) namun belum dijelaskan karakteristik dari variabel itu (apakah lainnya, kebijakan harga, promosi dan disribusi) pada objek yang diteliti belum terlaksana dengan baik, hal ini dijelaskan melalui penelitian deskriptif. 
Dalam hal teknik pengumpulan data menurut kegiatan yang dilakukan, maka teknik yang digunakan adalah survei lapangan (field survey). Survei lapangan dilakukan dengan cara pengisian kuisioner oleh konsumen yang membeli minuman produk Coca-Cola di Kota Padang. Kuisioner yang diberikan adalah kuisioner yang telah ditentukan jawabannya, responden hanya memilih satu dari beberapa jawaban yang ada.

\section{HASIL PENELITIAN DAN PEMBAHASAN}

\subsection{TEKNIS ANALISIS DATA DAN UJI HIPOTESA}

Teknis Analisa data dalam penelitian ini menggunakan regresi liner berganda, yaitu suatu pendekatan yang bertujuan untuk melihat sejauh mana kemampuan dari semua variabel bebas atau independen yang meliputi kebijakan harga (X1), promosi (X2) dan distribusi (X3) dalam menjelaskan atau mempengaruhi variabel terikat atau dependen yang dalam hal ini adalah variabel keputusan pembelian (Y). Namun sebelum dilakukan analisis regresi linear berganda, telah dilakukan pengujian persyaratan asumsi klasik yang meliputi uji normalitas, mutikolinearitas dan heteroskedastisitas. Dimana secara keseluruhan temuan menunjukan model yang dibangun dapat memenuhi model yang layak atau dapat menjelaskan kerangka konseptual yang telah dibentuk dalam menjelaskan hipotesis penelitian. berikut ini :

Berikut ringkasan hasil pengujian regresi linear berganda, sebagaimana yang tanpak pada table

Tabel 1 Hasil Nilai Koefisien Regresi

Coefficients ${ }^{a}$

\begin{tabular}{|c|c|c|c|c|c|c|}
\hline \multirow{2}{*}{\multicolumn{2}{|c|}{ Model }} & \multicolumn{2}{|c|}{ Unstandardized Coefficients } & \multirow{2}{*}{$\begin{array}{c}\text { Standardized } \\
\text { Coefficients } \\
\text { Beta } \\
\end{array}$} & \multirow[t]{2}{*}{$\mathrm{t}$} & \multirow[t]{2}{*}{ Sig. } \\
\hline & & $\mathrm{B}$ & Std. Error & & & \\
\hline \multirow{4}{*}{1} & (Constant) & 4,224 & 1,356 & & 3,115 &, 002 \\
\hline & KEBIJAKAN HARGA & 057 &, 078 &, 060 & ,734 &, 465 \\
\hline & PROMOSI & ,418 &, 084 & 445 & 4,949 &, 000 \\
\hline & DISTRIBUSI & 254 & 093 & ,248 & 2,745 &, 007 \\
\hline
\end{tabular}

a. Dependent Variable: KEPUTUSAN PEMBELIAN

ANOVA $^{\mathrm{a}}$

\begin{tabular}{|c|c|c|c|c|c|c|}
\hline \multicolumn{2}{|c|}{ Model } & Sum of Squares & df & Mean Square & $\mathrm{F}$ & Sig. \\
\hline \multirow{3}{*}{1} & Regression & 35,373 & 3 & 11,791 & 17,971 &, $000^{\mathrm{b}}$ \\
\hline & Residual & 62,987 & 96 & ,656 & & \\
\hline & Total & 98,360 & 99 & & & \\
\hline
\end{tabular}

\section{a. Dependent Variable: KEPUTUSAN PEMBELIAN}

b. Predictors: (Constant), DISTRIBUSI, KEBIJAKAN HARGA, PROMOSI

Sumber : hasil pengolahan data SPSS.

Berdasarkan ringkasan hasil regresi linear di atas, secara keseluruhan semua variabel yang meliputi kebijakan harga (X1), promosi (X2) dan distribusi (X3) dapat mempengaruhi variabel keputusan pembelian (Y) sebagai variabel dependen. Variabel kebijakan harga (X1) mempunyai nilai signifikannya di atas $€=5 \%$ sehingga berpengatuh tidak signifikan terhadap keputusan pembelian. Sedangkan nilai signifikan varuabel promosi (X2) dan distribusi (X3) nilai signifikannya dibawah $€=5 \%$ 
maka kedua variabel tersebut berpangaruh dan signifikan terhadap keputusan pembelian. Dengan demikian dapat dibentuk persamaan regresi linear berganda sebagai berikut :

$$
\mathrm{Y}=4.224+0.057 \mathrm{X} 1+0.418 \times 2+0.254 \times 3+\mathrm{e}
$$

\subsection{Pengaruh Kebijakan Harga terhadap Keputusan Pembelian}

Berdasarkan hasil regresi linear berganda pada tabel 1 di atas, ditemukan nilai koefisien regresi kebijakan harga sebesar 0.057 dengan nilai signifikan 0.465 yang jika dibandingkan dengan kesalahan menolak data sebesar 0.05 nilai ini relatif tinggi. Dengan demikian dapat disimpulkan bahwa kebijakan harga mempunyai pengaruh positif tetapi tidak signifikan terhadap keputusan pembelian minuman produk Coca-Cola di Kota Padang. Koefisien regresi variabel kebijakan harga 0.057 yang artinya bilamana kebijakan harga ditingkatkan satu (1) satuan bobot dengan asumsi promosi dan distribusi diabaikan (0), maka akan meningkatkan keputusan pembelian sebesar 0.057 satuan bobot, begitu juga sebaliknya.

Hasil temuan ini sejalan dengan landasan teori yang diungkapkan oleh Kotler dalam Birrul (2009) yang menyatakan bahwa kebijakan harga adalah suatu alat atau cara yang dipergunakan perusahaan untuk menetapkan harga dan bisa mempengaruhi konsumen dalam melakukan pembelian terhadap barang yang ditawarkan.

\subsection{Pengaruh Promosi Terhadap Keputusan Pembelian}

Berdasarkan hasil regresi linear berganda pada tabel 1 di atas, ditemukan nilai koefisien regresi promosi sebesar 0.418 dengan nilai signifikan 0.000 yang jika dibandingkan dengan kesalahan menolak data sebesar 0.05 nilai ini relatif rendah. Dengan demikian dapat disimpulkan bahwa promosi mempunyai pengaruh positif dan signifikan terhadap keputusan pembelian minuman produk Coca-Cola di Kota Padang. Koefisien regresi variabel kebijakan harga 0.418 yang artinya bilamana promosi ditingkatkan satu (1) satuan bobot dengan asumsi kebijakan harga dan distribusi diabaikan (0), maka akan meningkatkan keputusan pembelian sebesar 0.418 satuan bobot, begitu juga sebaliknya.

Hasil temuan ini sejalan dengan landasan teori yang diungkapkan oleh Martin L. Bell dalam Swastha dan Irawan (2005) yang menyatakan bahwa promosi adalah semua jenis kegiatan pemasaran yang ditujukan untuk mendorong permintaan konsumen. Disisi lain Fandy Tjiptono (2008) menyatakan promosi penjualan adalah bentuk persuasi langsung melalui penggunaan berbagai insentif yang dapat diatur untuk merangsang pembelian produk dengan segera dan meningkatkan jumlah barang yang dibeli pelanggan. Hal yang sama juga sejalan dengan teori Buchri Alma (2006) yang menyatakan bahwa promosi adalah sejenis komunikasi yang memberikan penjelasan dan meyakinkan calon konsumen. Hasil temuan ini relevan dan dapat memperkuat penelitian Imam Heryanto (2015) yang menyatakan bahwa promosi berpengaruh positif dan signifikan terhadap keputusan pembelian serta implikasinya pada kepuasan pelanggan.

\subsection{Pengaruh Distribusi Terhadap Keputusan Pembelian}

Berdasarkan hasil regresi linear berganda pada tabel 1 di atas, ditemukan nilai koefisien regresi distribusi sebesar 0.254 dengan nilai signifikan 0.007 yang jika dibandingkan dengan kesalahan menolak data sebesar 0.05 nilai ini relatif rendah. Dengan demikian dapat disimpulkan bahwa distribusi mempunyai pengaruh positif dan signifikan terhadap keputusan pembelian minuman produk Coca-Cola di Kota Padang. Koefisien regresi variabel distribusi 0.254 yang artinya bilamana distribusi ditingkatkan satu (1) satuan bobot dengan asumsi kebijakan harga dan promosi diabaikan (0), maka akan meningkatkan keputusan pembelian sebesar 0.254 satuan bobot, begitu juga sebaliknya. 
Hasil temuan ini sejalan dengan landasan teori yang diungkapkan oleh Kotler (2005) yang menyatakan bahwa distribusi mencakup perencanaan, pelaksanaan dan pengawasan arus bahan dengan memperoleh produk akhir dari tempat produksi akan memperoleh keuntungan. Hasil temuan ini relevan dan dapat memperkuat penelitian Imam Heryanto (2015) yang menyatakan bahwa distribusi berpengaruh positif dan signifikan terhadap keputusan pembelian serta implikasinya pada kepuasan pelanggan.

\subsection{Pengaruh Kebijakan Harga,Promosi dan Distribusi Terhadap Keputusan Pembelian}

Penilaian pengaruh secara serentak/simultan dari semua variabel independen yang meliputi kebijakan harga, promosi dan distribusi terhadap keputusan pembelian minuman produk Coca-Cola di Kota Padang dapat dinilai melalui $\mathrm{F}$ dan signifikannya, dimana nilai $\mathrm{F}$ adalah 17.971 dengan nilai signifikan sebesar 0.000. Nlai signifikan yang dihasilkan ini jika dibandingkan dengan alpha atau kesalahan menolak data sebesar 0.05 jauh lebih rendah $(0.000<0.05)$. Hal ini dapat diartikan secara serentak/simultan kebijakan harga, promosi dan distribusi mempuyai pengaruh positif dan signifikan terhadap keputusan pembelian minuman produk Coca-Cola di Kota Padang. Dengan kata lain ketiga variabel penelitian ini adalah faktor yang memang dapat menentukan dan mempengaruhi keputusan pembelian minuman produk Coca-Cola di Kota Padang.

\section{KESIMPULAN}

Berdasarkan dari analisis data dan intreprestasi hasil penelitian serta pembahasan hasil yang telah disampaikan sebelumnya, maka dapat ditarik beberapa kesimpulan sebagai berikut :

1. Secara parsial variabel kebijakan harga berpengaruh positif tetapi tidak signifikan terhadap keputusan pembelian minuman produk Coca-Cola di Kota Padang.

2. Secara parsial variabel promosi berpengaruh positif dan signifikan terhadap keputusan pembelian minuman produk Coca-Cola di Kota Padang.

3. Secara parsial variabel distribusi berpengaruh positif dan signifikan terhadap keputusan pembelian minuman produk Coca-Cola di Kota Padang.

4. Secara serentak/simultan variabel kebijakan harga, promosi dan distribusi berpengaruh positif dan signifikan terhadap keputusan pembelian minuman produk Coca-Cola di Kota Padang.

\section{DAFTAR PUSTAKA}

[1] Buchari Alma; 2011. Manajemen Pemasaran dan Pemasaran Jasa. Bandung : Penerbit Alfabeta

[2] Buchari Alma; 2006. Pemasaran dan Pemasaran Jasa, Alfabeta, Bandung.

[3] Sangadji, Etta Mamang dan Sopiah; 2013. Perilaku Konsumen : Pendekatan Praktis Disertai Himpunan Jurnal Penelitian. Edisi pertama. Yogyakarta : Andi

[4]Kotler; 1991. Pengertian Saluran Distribusi diakses dari http://jurnalsdm.blogspot.com/2009/11/saluran-distribusi-definisi-fungsi-dan.html

[5] Kotler, Philip; 2009. Manajemen Pemasaran. Jakarta : Erlangga

[6] Basu, Swastha dan Irawan; 1997. Manajemen Pemasaran Modern. Yogyakarta: Liberty.

[7] Stanton, William J; 2003. Prinsip Pemasaran. Alih Bahasa oleh Sadu Sundaru. Jilid Satu. Edisi Kesepuluh. Jakarta : Erlangga.

[8] Tjiptono, Fandy; 2009., Strategi Pemasaan, Yogyakarta : Penerbit Andi

[9] Basu Swastha dan Irawan; 2005, Asas-asas Marketing, Liberty, Yogyakarta.

[10] Tjiptono, Fandy; 2008., Strategi Pemasaan, Yogyakarta : Penerbit Andi Drs Djaslim Saladin, 2004, Manajemen Pemasaran, Linda Karya, Bandung 
[11] Kotler, Philip; 2005. Manajamen Pemasaran, Jilid 1 dan 2. Jakarta: PT. Indeks Kelompok Gramedia.

[12] Sangadji, Etta Mamang dan Sopiah; 2013. Perilaku Konsumen : Pendekatan Praktis Disertai Himpunan Jurnal Penelitian. Edisi pertama. Yogyakarta : Andi.

[13] Abdullah, Thamrin dan Francis Tantri; 2012. Manajemen Pemasaran. Depok : PT Raja Grafindo Persada

[14] Yudhi Koesworodjati; 2006, Prinsip Dasar Manajemen Pemasaran, FE UNPAS,Bandung.

[15] Kotler dan Keller; 2007. Manajemen Pemasaran, Edisi 12, Jilid 1, PT.Indeks, Jakarta.

[16] Keegan J, warren; 1996. Managemen Pemasaran Global Jild II

[17] Hair, J.et al; 1998. Multivavariate Data Analysis. New Jersey. Prentice-Hall

[18] Kotler, Philip; 1995, diterjemahkan oleh Ancella Anitawai Hermawan, SE, MBA, Manajemen Pemasaran : Analisis, Perencanaan, Implementasi Dan Pengendalian, Buku Dua, Edisi ke-8, Indonesia, Salemba Empat, Prentice Hall.

[19] Masngudi Prof. Dr. SE; 2012, Metodologi Penelitian Untuk Ekonomi dan Bisnis. Jakarta, Trianandra University Press.

[20] Dwi Priyatno; 2008 Mandiri Belajar SPSS. Yogyakarta, Mediakom

[21] Gujarati N. Damodar; 2004. Basic Econometrics fourth edition. McGraw-Hill

[22] Sugiyono; 2014. Metode Penelitian Pendidikan Pendekatan Kuantitatif, Kualitatif Dan R\&D. Bandung: Alfabeta.

[23] Hendra fure; (2013). Lokasi, keneragaman Produk, Harga, dan kualitas Pelayanan [24] Pengaruhnya Terhadap Minat Beli pada Pasar Tradisional Bersehati Calaca, Jurnal EMBA. Vol.1 No.3

(1) Birrul, Moh; (2009). Pengaruh Kebijakan Harga terhadap keputusan pembelian di Branch Office (BO) Bumilindo Prakarsa Probolinggo. Tidak dipublikasikan

(2) Basu Swastha \& Irawan; (2005). Manajemen Pemasaran Modern. Liberty, Yogyakarta

(3) Imam Heryanto; 2015. Analisis Pengaruh Poduk, harga, Distribusi, dan Promosi terhadap Keputusan Pembelian Serta Implikasinya Pada Keputusan Pelanggan. Tesis (STIE Pasundan Bandung) 